\title{
The Preservation of Inuit Clothing Collected during the Fifth Thule Expedition (1921-24)
}

\author{
LARS CARLSEN,${ }^{1}$ ANDERS FELDTHUS ${ }^{2}$ and ANNE LISBETH SCHMIDT ${ }^{3}$
}

\author{
(Received 18 August 1994; accepted in revised form 8 April 1995)
}

\begin{abstract}
Preparation procedures as well as ordinary use apparently cause changes in the appearance of Inuit skin clothing. These changes may alter the inherent properties of skin, such as fatty acid composition and shrinkage temperature. The present paper describes studies of fatty acid distribution and shrinkage temperature in a series of items of Inuit origin collected during the Fifth Thule Expedition (1921-24). The skins used for the clothing originate from ringed seal (Phoca hispida) and caribou (Rangifertarandus). For comparison, freshly prepared skins were studied, as were samples of sealskins found in the mummy burial ground in Qilakitsoq, Greenland. It appeared that ordinary use changed the fatty acid distribution to some extent, as well as the shrinkage temperature, indicating slow deterioration. However, more significant deterioration was observed for samples exposed for longer periods to daylight as, for example, when placed on exhibition. The effect of light was verified by studying samples deliberately exposed to full daylight for ca. 6 months. In contrast to these samples, the 500-year-old skins appeared, on the basis of fatty acid distribution and shrinkage temperature, to be in good condition, possibly because of the lack of ordinary use in combination with low storage temperatures.
\end{abstract}

Key words: Inuit, clothing, skin preparation, tanning, seal, caribou, fatty acid, preservation, Fifth Thule Expedition

RÉSUMÉ. Les méthodes de préparation ainsi que l'utilisation normale provoquent, semble-t-il, des changements dans l'aspect des vêtements de peau inuit. Ces changements peuvent modifier les propriétés inhérentes de la peau, telles que la répartition des acides gras et la contractilité thermique. Cet article décrit les études portant sur la répartition des acides gras et la contractilité thermique dans une série d'objets d'origine inuit recueillis au cours de la cinquième expédition de Thulé (1921-24). Les peaux servant à l'habillement viennent du phoque annelé (Phoca hispida) et du caribou (Rangifer tarandus). À des fins de comparaison, on a étudié des peaux récemment préparées, ainsi que des échantillons de peaux de phoque trouvées dans le cimetière de momies de Qilakitsoq, au Groenland. Il semble que l'utilisation normale ait changé, dans une certaine mesure, la répartition des acides gras ainsi que la contractilité thermique, indiquant une détérioration lente. On a toutefois observé une détérioration plus importante pour des échantillons exposés durant de plus longues périodes à la lumière naturelle comme, par exemple, lorsqu'ils sont mis en exposition. On a vérifié l'effet de la lumière en étudiant des échantillons délibérément exposés au grand jour pendant environ six mois. Par contraste avec ces échantillons, les peaux de 500 ans semblaient, si l'on se fiait à la répartition des acides gras et à la contractilité thermique, en bon état, et ce, en raison peut-être du manque d'utilisation courante combiné à un entreposage à basse température.

Mots clés: inuit, habillement, préparation de la peau, tannage, phoque, caribou, acide gras, conservation, cinquième expédition de Thulé

Traduit pour la revue Arctic par Nésida Loyer.

\section{INTRODUCTION}

The National Museum in Copenhagen holds one of the world's largest collections of archeological and ethnographic items of Inuit origin. The most important and best-documented collection of items was obtained during the Fifth Thule Expedition, the Danish Ethnographic Expedition to Arctic North America (1921-24), while its members were in the Canadian Arctic to study the Inuit migration from North America to Greenland. Their research was based on archaeo- logical finds and ethnographic study of the present generation of Inuit living in the central region of arctic North America at the time (Report of the Fifth Thule Expedition, 1928-46). A significant part of the collection consists of skin clothing. Typically, Inuit skin clothing was prepared fom the skins of seal or caribou.

In the period 1936-70, several of the items were on display in rooms at the National Museum exposed to full daylight. Between 1970 and 1975 the items were in storage as the exhibition area was under construction. From 1975 to

\footnotetext{
${ }^{1}$ National Environmental Research Institute, Department of Environmental Chemistry, DK-4000 Roskilde, Denmark

${ }^{2}$ Ris $\emptyset$ National Laboratory, Department of Combustion Research, DK-4000 Roskilde, Denmark; present address: Analytical Instruments, Kirke Vœrløsevej 14, DK-3500 Vœrløse, Denmark

${ }^{3}$ The National Museum of Denmark, Department of Conservation, P.O. Box 260, Brede, DK-2800 Lyngby, Denmark

(C) The Arctic Institute of North America
} 
1989, the exhibition was in dimmed rooms, using showcases with built-in light sources.

Items not on exhibition were stored in dusty stores with varying temperature and moisture content. Insect attacks were controlled with a variety of insecticides comprising among others DDT, Lindane and p-dichloro benzene (Glastrup, 1987). Damage by water caused the growth of mould fungus. Attempts were made to control the latter by gassing with carbon disulfide and ethylene oxide. In 1985-86 all items were cleaned by removing the insecticides with pressurized air, filled with acid-free tissue paper and subsequently packed in acid-free cardboard boxes and stored in renovated (but not air-conditioned) stores.

During the cleaning procedure it was observed that the individual skin clothing items varied significantly in appearance, with regard to both colour and stiffness, and in smell. It should in this context be emphasized that the items comprise worn as well as unused clothing. The observed differences in colour and stiffness may be related to the state of preservation (Schmidt, 1991). However, because none of these subjective observations could immediately be related to the state of preservation, they have not been included in the present study.

The skin preparation procedures, which typically involved stretching, scraping and biting (Schmidt et al., 1993), obviously may be responsible for changes in skin appearance as well as skin characteristics. Thus, in a recent paper (Schmidt et al., 1993), we reported on the variation of fatty acid distribution and shrinkage temperature as a function of skin preparation.

In nature fat is present in a variety of forms. In animal cells and tissues, fatty acids are often found in combination with other organic components (e.g., as triglycerides). The fatty acid distribution appears as a combination of saturated, mono-unsaturated and polyunsaturated constituents, the ratio between these being typical for the single species. The interrelations between the single fatty acids can be affected by the preparing procedure. However, exposure to daylight may also influence the fatty acid distribution. In both cases, so-called auto-oxidation appears responsible for the disappearance of the mono- and polyunsaturated fatty acid constituents (Mills, 1966; Jovanovic and Josimovic, 1992). The auto-oxidation leads to lower acids as well as aldehydes. Thus, the process does not lead to a simple saturation (Mills, 1966; Jovanovic and Josimovic, 1992).

\section{METHODS}

In the present study Inuit skin clothing of ringed seal (Phoca hispida) and caribou (Rangifer tarandus) were studied, originating from the Iglulik, Caribou, Netsilik and Copper Inuit bands. Items which have been on exhibition for up to 50 years as well as items from the stores have been studied. As reference material, raw skins of both species were studied, as was 500-year-old skin of ringed seal originating from the Qilakitsoq mummy burial ground in the Uummannaq district in Northwest Greenland (Hart Hansen and Gulløv, 1989). Eight well-preserved mummies were found there, all dressed in skin clothes and wrapped in whole skins of seal and caribou. The mummies were determined by $\mathrm{C}-14$ dating to originate from the year $1475 \pm 50$ years (Hart Hansen and Gulløv, 1989).

In total, skins from ten samples have been investigated (the figures given in parentheses denote the corresponding age): Sample A (2-5 years): untreated seal and caribou skin (Schmidt et al., 1993); Sample B (2-5 years): seal and caribou skin freshly prepared according to the Inuit stretching-scraping-biting procedure (Schmidt et al., 1993); Sample C (2 -5 years): caribou skin samples de-haired before prepartion (Schmidt et al., 1993); Sample D (ca. 500 years): skin of ringed seal from the Qilakitsoq mummy burial ground (Hart Hansen and Gulløv, 1989); Samples E, F and G (ca. 70 years): items of skin clothing collected during the Fifth Thule Expedition and placed in store houses for not less than 30 years (E: hairy without epidermis; F: hairy with epidermis; G: de-haired without epidermis); Sample H (ca. 20 years): hairy skins placed on exhibition for ca. 20 years; Sample I (ca. 20 years): hairy skins placed on exhibition for ca. 20 years and subsequently exposed to broad daylight for ca. 6 months; and Sample J (ca. 70 years): items of hairy skin clothing collected during the Fifth Thule Expedition and placed on exhibition for up to 50 years.

\section{Fatty Acid Analyses}

For fatty acid analysis, $2 \mathrm{mg}$ of tissue (corium) were cut into fine pieces and mixed with $0.5 \mathrm{~mL}$ tetrahydrofuran (freshly distilled, not stabilized). The suspension was left for 12 to $18 \mathrm{~h}$, which were followed by $0.5 \mathrm{~h}$ in an ultrasonic bath to achieve complete homogenization of the sample.

Transformation of the triglycerides into the corresponding methyl esters was accomplished by adding $1 \mathrm{~mL}$ of sodium methoxide (ca. $3 \mathrm{~g}$ of metallic Na to $100 \mathrm{~mL}$ methanol) to the sample. The sample was left for $0.5 \mathrm{~h}$ in an ultrasonic bath. Subsequently $1 \mathrm{~mL} \mathrm{NaCl}$ solution and $1 \mathrm{~mL}$ concentrated $\mathrm{H}_{2} \mathrm{SO}_{4}$ were added to the solution.

The fatty acid methyl esters were extracted with pentane. The pentane phase was dried $\left(\mathrm{Na}_{2} \mathrm{SO}_{4}\right)$, and evaporated to a volume of ca. $100 \mu \mathrm{L}$. The concentrates were analysed on a Hewlett-Packard HP 5890 A gaschromatograph equipped with a flame ionization detector (FID). The analyses were carried out using a CP-Sil 88 column (Chrompack), with helium as carrier gas. The identification of fatty acid methyl esters was established by comparison with standard solutions analyzed under similar conditions.

\section{Shrinkage Temperature Analyses}

The shrinkage temperature is defined as the temperature (in water) at which the collagen in skin denaturates (i.e., is irreversibly destroyed). During denaturation the material shrinks to approximately $35 \%$ of its original size. The shrinkage temperatures of fresh skins of mammals are found in the range from $62^{\circ}$ to $68^{\circ} \mathrm{C}$ (Young, 1990), whereas certain mineral-tanned leathers exhibit shrinkage temperatures of 
$>100^{\circ} \mathrm{C}$ (Young, 1990). Deterioration apparently causes a decrease in shrinkage temperature (Larsen et al., 1993). Thus, the shrinkage temperature constitutes a valuable indicator of the possible degree of deterioration of the skin material (Young, 1990; Larsen et al., 1993).

A small portion of finely dispersed material was degreased with a few drops of acetone. The degreasing appears essential to ensure the subsequent saturation of the fibres with water. Before the acetone was evaporated, $1 \mathrm{~mL}$ of distilled water was added and the sample was left for $15 \mathrm{~min}$. in order to achieve complete swelling of the fibres, as the swelling influences the stability of the collagen until equilibrium is achieved. Thus, the shrinkage temperature is a measure of the remaining stability of the collagen (Young, 1990).

The shape of the fibres as a function of increased temperature was followed microscopically, the samples being placed in sealed, hollow-grounded object glasses to secure free movement of the fibres without evaporation of the water. The samples were heated on a Mettler FP 82 HT Hot Stage with a temperature gradient of $3^{\circ} \mathrm{C}$ per min. controlled by a Mettler FP 80 HT Central Processor. Before denaturation the fibres appeared as silver-shining, transparent and crystalline slightly folded bands. The progressing denaturation with increasing temperature was recognized as a decreasing transparency and increasing shrinkage of the single fibres. We have defined the initial shrinkage temperature $\left(\mathrm{T}_{\mathrm{i}}\right)$ as that at which approximately $50 \%$ of the fibres have lost their transparency. The final temperature $\left(T_{f}\right)$ is defined as that at which ca. $90 \%$ of the fibres are denaturated. The difference $T_{f}-T_{i}$ is defined as $T_{d}$. An effective preparation of the skin will be recognized as an increased $\mathrm{T}_{\mathrm{i}}$ and a small $\mathrm{T}_{\mathrm{d}}$ (Young, 1990; Larsen et al., 1993).

\section{RESULTS AND DISCUSSION}

In a recent paper on changes of skin characteristics through the Inuit preparing procedure, we demonstrated the effectiveness of the stretching-scraping-biting sequence (Schmidt et al., 1993). Decreases in the content of unsaturated fatty acids were noted, with a simultaneous increase in the shrinkage temperature. Thus, possible deterioration of the material is expected to be reflected in the changes in fatty acid distribution and shrinkage temperatures.

Significant differences in the fatty acid distributions in skins from seal and caribou prevail. In Table 1 the distributions of the acids are given as the relative amounts of saturated, mono- and polyunsaturated fatty acid residues in skins

TABLE 1 . Fatty acid distribution in skins originating from seal and caribou (percent of total).

\begin{tabular}{lrc}
\hline \hline & Seal & Caribou \\
\hline Saturated & 9.6 & 38.7 \\
Mono-unsaturated & 65.0 & 52.7 \\
Polyunsaturated & 25.4 & 8.6 \\
Unsaturated (total) & 90.4 & 61.3 \\
\hline \hline
\end{tabular}

originating from seal and caribou, respectively. The obtained values are in good agreement with previously reported values for seal blubber (Innis and Kuhnlein, 1987; West et al., 1979) and caribou fatty tissue (West et al., 1979; Shukla et al., 1980).

The predominance of mono- and polyunsaturated fatty acids in seal skin is immediately noted in contrast to the relatively high content of saturated fatty acids in caribou skin.

In this study, we focussed on the variations in the fatty acids more abundant in nature (i.e., C16:0, C16:1, C18:0 and $\mathrm{C} 18: 1)$, which in unprepared seal and caribou skins were found to account for respectively $60.8 \%$ and $89.2 \%$ of the total amount of fatty acids (cf. Table 2 ; see also, for example, West et al., 1979; Shukla et al., 1980). The corresponding figures for the prepared skins (Schmidt et al., 1993) are 82.2\% and $92.1-92.5 \%$, respectively. Accordingly, the combined abundances of $\mathrm{C} 16: 0+\mathrm{C} 18: 0\left(\mathrm{r}_{\text {sat }}\right)$ and C16:1 $+\mathrm{C} 18: 1\left(\mathrm{r}_{\text {unsat }}\right)$ are used as a measure of the distribution of saturated and unsaturated fatty acids in the skin samples, respectively. Table 2 gives the average values for $r_{\text {sat }}$ and $r_{\text {unsat }}$ as well as the total contribution of the four fatty acids $\left(r_{\text {tot }}=r_{\text {sat }}+r_{\text {unsat }}\right)$ for the individual skin samples investigated. It should be noted that the values given are simple arithmetic averages; the variations are given in parentheses. Because the number of items available was rather limited, no statistical treatment of the data has been conducted.

In Table 3 the average shrinkage temperatures for the investigated samples of skin items are given, with the variations in parentheses.

The influence of the preparing procedure on fatty acid distribution and shrinkage temperature has been described previously (Schmidt et al., 1993). In the case of the seal skins it is evident (cf. Table 2) that the items originating from the Fifth Thule Expedition (samples E, F, G, and J) exhibit distinct variations compared to the freshly prepared skin (sample B). Thus, a somewhat increased $r_{\text {sat }}$ can be noted, which, however, appears to be compensated only to a certain extent by a corresponding decrease in $\mathrm{r}_{\text {unsar }}$. The most prominent effect is noted for the skins in sample $\mathrm{G}$ (de-haired skins) and $\mathbf{J}$ (items on exhibition for up to 50 years). Apparently the de-hairing process significantly influenced the fatty acid distribution, decreasing the content of the unsaturated compounds, most probably by oxidation (Hart Hansen and Gulløv, 1989). The items which have been on exhibition for prolonged periods, partly in full daylight, revealed a significant shift towards saturated fatty acids. Some of the observed variations may have been introduced by the normal wear of the clothing before the actual collection by the expedition.

It is interesting to note that the skins originating from the Qilakitsoq mummy burial ground (sample D) (Hart Hansen and Gulløv, 1989) exhibit a virtually identical fatty acid distribution as found in the freshly prepared skin, the results being in excellent agreement with previous studies on skin samples from Qilakitsoq (Ammitzbøll et al., 1989). It seems reasonable to assume that the low storage temperatures and extremely dry air have allowed a freeze-drying of the skins. This significantly decreased the reaction rates for, if not eliminated the processes leading to oxidative denaturation of 
TABLE 2. Abundances of saturated $\left(\mathrm{r}_{\text {sat }}\right)$ and unsaturated $\left(\mathrm{r}_{\text {unsat }}\right) \mathrm{C} 16+\mathrm{C} 18$ fatty acids in skin samples from seal and caribou.

\begin{tabular}{|c|c|c|c|c|c|c|c|c|c|c|c|c|c|c|}
\hline \multirow{3}{*}{$\begin{array}{c}\text { Sample } \\
\text { A }\end{array}$} & \multirow[t]{3}{*}{$\#^{1}$} & \multicolumn{6}{|c|}{ Seal } & \multirow[t]{2}{*}{$\#^{1}$} & \multicolumn{6}{|c|}{ Caribou } \\
\hline & & \multicolumn{2}{|c|}{$\mathrm{r}_{\text {sat }}$} & \multicolumn{2}{|c|}{$\mathrm{r}_{\text {unsat }}$} & \multicolumn{2}{|c|}{$\mathrm{r}_{\mathrm{tot}}^{2}$} & & \multicolumn{2}{|c|}{$r_{\text {sat }}$} & \multicolumn{2}{|c|}{$\mathrm{r}_{\text {unsat }}$} & \multicolumn{2}{|c|}{$\mathrm{r}_{\mathrm{tot}}^{2}$} \\
\hline & & 5.4 & & 55.4 & & 60.8 & & & 36.5 & & 52.7 & & 89.2 & \\
\hline B & 3 & 14.2 & (1.6) & 68.0 & (2.9) & 82.2 & (1.4) & 2 & 39.5 & (0.9) & 52.5 & (4.9) & 92.1 & (5.5) \\
\hline $\mathrm{C}$ & & - & & - & & - & & $2^{3}$ & 66.5 & (8.6) & 26.3 & (6.0) & 92.8 & (2.6) \\
\hline $\mathrm{D}$ & 2 & 13.1 & (3.7) & 69.2 & (3.6) & 82.3 & $(0.1)$ & & - & & - & & - & \\
\hline E & 2 & 31.3 & (6.1) & 62.2 & (8.9) & 93.5 & (2.9) & 21 & 42.3 & (13.6) & 46.2 & (11.1) & 88.5 & (5.7) \\
\hline $\mathrm{F}$ & 8 & 29.7 & (12.1) & 61.1 & (12.6) & 90.8 & (2.0) & & - & & - & & - & \\
\hline G & 6 & 32.0 & (10.5) & 51.8 & $(9.9)$ & 83.7 & (4.8) & $2^{3}$ & 84.7 & $(0.8)$ & 11.6 & $(0.1)$ & 96.3 & (0.9) \\
\hline $\mathrm{J}$ & 3 & 33.9 & $(6.1)$ & 47.6 & (5.8) & 81.5 & (1.0) & 6 & 88.3 & $(11.1)$ & 4.5 & (2.5) & 92.8 & (9.2) \\
\hline $\mathrm{H}$ & 3 & 10.6 & (1.6) & 71.0 & $(0.8)$ & 81.6 & (1.3) & 2 & 45.0 & (5.6) & 39.3 & $(4.0)$ & 84.3 & (1.6) \\
\hline I & 1 & 40.4 & & 24.0 & & 64.4 & & 1 & 62.3 & & 24.4 & & 86.7 & \\
\hline
\end{tabular}

${ }^{1}$ \# denotes the number of samples investigated within the single groups.

${ }^{2} r_{\text {tot }}=r_{\text {sat }}+r_{\text {unsat }}$.

${ }^{3}$ De-haired (cf. Schmidt et al., 1993).

TABLE 3. Shrinkage temperatures $\left(\mathrm{T}_{\mathrm{i}}, \mathrm{T}_{\mathrm{f}}, \mathrm{T}_{\mathrm{d}}\right)$ for skin samples from seal and caribou.

\begin{tabular}{|c|c|c|c|c|c|c|c|c|c|c|c|c|c|c|}
\hline \multirow{3}{*}{$\begin{array}{c}\text { Sample } \\
\text { A }\end{array}$} & \multirow[t]{3}{*}{$\#$} & \multicolumn{6}{|c|}{ Seal } & \multirow[t]{3}{*}{$\#^{1}$} & \multicolumn{6}{|c|}{ Caribou } \\
\hline & & \multicolumn{2}{|c|}{$\mathrm{T}_{\mathrm{i}}$} & \multicolumn{2}{|c|}{$\mathrm{T}_{\mathrm{f}}$} & \multicolumn{2}{|c|}{$\mathrm{T}_{\mathrm{d}}^{2}$} & & \multicolumn{2}{|c|}{$\mathrm{T}_{\mathrm{i}}$} & \multicolumn{2}{|c|}{$\mathrm{T}_{\mathrm{f}}$} & \multicolumn{2}{|c|}{$\mathrm{T}_{\mathrm{d}}^{2}$} \\
\hline & & 53.1 & & 60.6 & & 7.5 & & & 54.6 & & 60.8 & & 6.2 & \\
\hline B & 2 & 62.7 & $(0.5)$ & 67.5 & (1.6) & 4.7 & (1.1) & 10 & 59.7 & (4.3) & 65.6 & (4.6) & 6.0 & (1.5) \\
\hline $\mathrm{C}$ & & - & & - & & - & & $2^{3}$ & 56.8 & (0.7) & 67.1 & (1.0) & 10.3 & (1.7) \\
\hline $\mathrm{D}$ & 2 & 57.6 & (3.6) & 63.3 & (3.5) & 5.7 & $(0.3)$ & & - & & - & & - & \\
\hline E & 6 & 63.2 & $(4.1)$ & 69.2 & (3.7) & 6.0 & (1.1) & 36 & 61.4 & $(3.2)$ & 69.2 & (2.4) & 7.8 & (2.3) \\
\hline $\mathrm{F}$ & 13 & 65.7 & (2.4) & 71.5 & (1.9) & 5.9 & (1.6) & & - & & - & & - & \\
\hline $\mathrm{G}$ & 6 & 57.9 & $(1.5)$ & 68.5 & $(1.5)$ & 10.8 & $(1.7)$ & $2^{3}$ & 59.1 & $(2.0)$ & 63.9 & (2.7) & 4.9 & $(0.9)$ \\
\hline $\mathrm{J}$ & 3 & 61.8 & $(0.5)$ & 69.5 & $(0.8)$ & 7.7 & (1.3) & 7 & 57.6 & (8.0) & 67.2 & (5.5) & 9.6 & (3.2) \\
\hline $\mathrm{H}$ & 11 & 55.2 & $(2.0)$ & 67.8 & $(2.7)$ & 12.6 & (2.6) & 2 & 43.9 & (5.0) & 57.9 & $(2.5)$ & 14.0 & (2.4) \\
\hline I & 1 & 41.4 & & 62.8 & & 21.4 & & 1 & 40.2 & & 52.6 & & 12.4 & \\
\hline
\end{tabular}

${ }^{1}$ \# denotes the number of samples investigated within the single groups.

${ }^{2} \mathrm{~T}_{\mathrm{d}}=\mathrm{T}_{\mathrm{f}}-\mathrm{T}_{\mathrm{i}}$.

${ }^{3}$ De-haired (cf. Schmidt et al., 1993).

the unsaturated components. Furthermore, it might well be that the skins used in the burial ground were freshly prepared at the time of the burial, so that deterioration due to normal wear had not developed.

Since the unsaturated fatty acids apparently are removed by an auto-oxidation process (Jovanovic and Josimovic, 1992) or by polymerization, it seems reasonable to assume that exposure to light, which often occurred during exhibition in the past, would cause variations in the relative abundance of the fatty acids, leading to an increased ratio of the saturated to the unsaturated compounds. The effect of daylight is unambiguously demonstrated by comparing samples $\mathrm{H}$ and I, the latter being identical to $\mathrm{H}$ as originating from the same skin, except that the hairless side of sample I had been exposed to daylight for about six months at room temperature. It should be emphasized that these skins ( $\mathrm{H}$ and $\mathrm{I}$ ) had been placed on exhibition for ca. 20 years, which means that to a certain extent they had been exposed to daylight, as was the case with the sample $\mathbf{J}$ items.

The possible deterioration indicated by the increased content of saturated fatty acids is a priori reflected in the corresponding shrinkage temperatures (Table 3). Thus, the skins originating from the Fifth Thule Expedition (samples E, F, G, and $J$ ) exhibit increased $T_{d}$ values, especially those that were de-haired $(\mathrm{G})$ and those that had been placed on exhibition (J). Similarly, a pronounced increase is noted for the skin $\mathrm{H}$, whereas virtually unchanged figures are noted in case of the Qilakitsoq samples. The most dramatic change is, not unexpectedly, noted for sample I, which showed a significantly decreased state of preservation following exposure to daylight for ca. six months. The broader shrinkage temperature ranges in the Thule sealskins may result from a greater heterogeneity in fibre hydration due to aging and possibly to a longer opportunity for oxidation and polymerization of the 
polyunsaturated fatty acid content, and as such do not necessarily indicate deterioration.

Turning to the items of caribou skin, qualitatively the same trends are noted (Tables 2 and 3), although the preparation method for the hairy skins (B) caused much less variation than observed for the sealskins (cf. Schmidt et al., 1993). As discussed previously (Schmidt et al., 1993), the de-hairing had a pronounced effect, although this is reflected in the shrinkage temperature for the freshly prepared skin (C) only, whereas the skins in sample $\mathrm{G}$, seem on the basis of shrinkage temperature, to be in good condition. As in the case of the sealskins, caribou skins placed on exhibition (samples $\mathbf{J}$ and $\mathrm{H})$ showed significantly changed fatty acid distributions as well as increased $T_{d}$ values, indicating some degree of deterioration, possibly due to the influence of light, as reflected in the figures obtained for sample I.

\section{CONCLUSION}

On the basis of the fatty acid distribution and the shrinkage temperature, it can be concluded that items of Inuit clothing collected during the Fifth Thule Expedition appear to be in a reasonably good state of preservation. Although this obviously was not the original aim of the preparation, the results strongly indicate the effectiveness of the Inuit preparation procedure. However, ordinary use may well account for some of the variations observed in the actual Inuit clothing compared to freshly prepared skins. As indicated by the experiments, exposure of skin samples to daylight for longer periods calls for attention, although changes due to normal wear to a certain extent may mask the effect. The 500-yearold sealskins from the Qilakitsoq mummy burial ground appear to be in a virtually unchanged state of preservation, similar to freshly prepared skins, possibly as a consequence of the lack of ordinary use combined with the low temperatures at which they have been stored.

\section{REFERENCES}

AMMITZBØLL, T., MØLLER, R., MØLLER, G., KOBAYASI, T., HINO, H., ASBOE-HANSEN, G., and HART HANSEN, J.P. 1989. Collagen and glycosaminoglycans in mummified skin. In: Hart Hansen, J.P., and Gulløv, H.C., eds. The mummies from Qilakitsoq - Eskimos in the 15th century. Meddelelser om Grønland, Man \& Society 12:93-99.

GLASTRUP, J. 1987. Insecticide analysis by gas chromatography in the stores of the Danish National Museum's ethnographic collection. Studies in Conservation 32:59-64.

HART HANSEN, J.P., and GULLØV, H.C., eds. 1989. The mummies from Qilakitsoq - Eskimos in the 15th century. Meddelelser om Grønland, Man \& Society, Vol. 12. 199 p.

INNIS, S.M. and KUHNLEIN, H.V. 1987. The Fatty Acid Composition of Northern Canadian Marine and Terrestrial Mammals, Acta Medica Scandinavica 222:105-109.

JOVANOVIC, S.V., and JOSIMOVIC, L.J.R. 1992. Radiation chemistry of fatty and amino acids. In: Patai, S., ed. The chemistry of acid derivatives. Suppl. B., Vol. 2. Chichester: Wiley. 1199-1248.

LARSEN, R., VEST, M., and NIELSEN, K. 1993. Determination of hydrothermal stability (shrinkage temperature) of historical leather by the micro hot table technique. Journal of the Society of Leather Technologists and Chemists 77:151-156.

MILLS, J.S. 1966. The gas chromatographic examination of paint media. Part I. Fatty acid composition and identification of dried oil films. Studies in Conservation 11:92-107.

REPORT OF THE FIFTH THULE EXPEDITION. 1928-46. The Danish Expedition to North America in Charge of Knud Rasmussen. Vols. 1-10. Copenhagen: Gyldendalske Forlag.

SCHMIDT, A.L. 1991. Eskimoiske Skinds Bevaringstilstand. Dissertation, Konservatorskolen, Det Kongelige Danske Kunstakademi, Copenhagen, Denmark. 32 p.

SCHMIDT, A.L., FELDTHUS, A., and CARLSEN, L. 1993. On the changes of skin characteristics through an Inuit tanning procedure. International Council of Museums, Committee for Conservation. Preprints for the 10th Triennial Meeting, Washington, D.C. Vol I:182-186.

SHUKLA, V.K.S., CLAUSEN, J., EGSGAARD, H., and LARSEN, E. 1980. The content of polyenoic acids in the major food sources of the Arctic diet. Fette, Seife und Anstrichmittel 82:193 199.

WEST, G.C., BURNS, J.J., and MODAFERI, M. 1979. Fatty acid composition of blubber from the four species of Bering Sea phocid seals. Canadian Journal of Zoology 57:189-195.

YOUNG, G.S. 1990. Microscopical hydrothermal stability measurements of skin and semitanned leather. International Council of Museums, Committee for Conservation. Preprints for the 9th Triennial Meeting, Dresden, German Democratic Republic. Vol II:626-631. 